THE INTERNATIONAL

REVIEW OF RESEARCH IN

OPEN AND DISTANCE LEARNING

\title{
Sense of Community in Graduate Online Education: Contribution of Learner to Learner Interaction
}
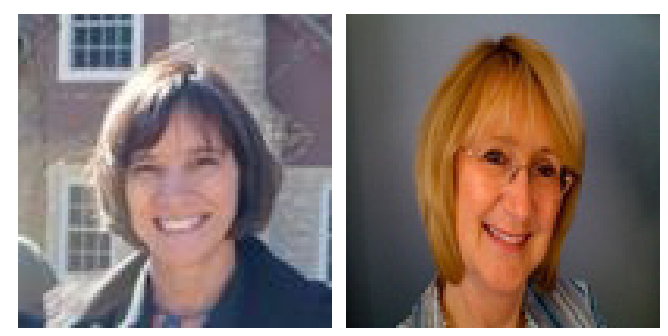

Jo L. Shackelford and Marge Maxwell Western Kentucky University, USA

\section{Abstract}

Distance learning technologies offer a multitude of ways to build interaction into online courses to support learning. Based on social constructivism theory, this study explored which types of interaction are most predictive of students' sense of community in online graduate courses at a regional comprehensive university. Surveys were used to measure sense of community and the frequency and importance of nine learner-learner interactions.

Interactions that were most predictive of sense of community were introductions, collaborative group projects, sharing personal experiences, entire class discussions, and exchanging resources. The interaction that offered the highest payoff to instructors was exchanging resources. The article discusses implications for online course design.

Keywords: Distance learning; online learning; distance education; building online community; exchanging resources; collaborative group projects

\section{Introduction}

Distance learning that makes use of online technology continues to outpace the growth of traditional education delivery, and enrolment in online courses has expanded steadily over the past two decades in higher education institutions in the United States (Parry, 2010). Availability of educational delivery options on the Internet does not, however, automatically create quality learning experiences. Instructors must use technologies and delivery formats strategically to create satisfying and high-quality educational experiences for students. 
Research supports the development of community in online learning as an important factor for maximizing student satisfaction with the experience (Liu, Magjuka, Bonk, \& Lee, 2007; Ouzts, 2006; Rovai, 2002a). As instructors consider the many course design options suggested in the literature for creating positive student experiences, they need information beyond expert opinion to guide them. They require empirical evidence to guide their design choices as they build into courses the interactive experiences that can create a community of learners.

The purpose of this study is to examine which types of learner to learner interactions contribute most to the development of students' sense of community (SoC) in online learning. $\mathrm{SoC}$ is defined in the literature as "a feeling that members have of belonging, a feeling that members matter to one another and to the group, and a shared faith that members' needs will be met through their commitment to be together" (McMillan \& Chavis, p. 9).

Interaction is defined as "reciprocal events that require at least two objects and two actions" (Wagner, 1994, p. 8). Learner-learner interaction (L-L) is communication between students, in pairs or groups, with or without an instructor present (Moore, 1989). Other types of interaction such as learner-instructor, learner-content (Moore, 1989), and learner-interface (Hillman, Willis, \& Gunawardena, 1994) are not within the scope of this study.

An environment that facilitates the development of a classroom community can be established in an online environment (Rovai, 2001). Purposeful design of courses that minimize student isolation can enhance community in online learning (McInnerney \& Roberts, 2004; Yang \& Liu, 2008).

There is evidence to support the importance of building community for social reinforcement (Conrad, 2005; Gallagher-LePak, Reilly, \& Killion, 2009; Moller, 1998), information exchange (Moller, 1998), and student outcomes (Anderson \& Elloumi, 2004; Drouin, 2008; Exter, Korkmaz, Harlin, \& Bichelmeyer, 2009; Liu et al., 2007; Shea, 2006; Shea, Li, \& Pickett, 2006; Wegerif, 1998).

Studies support the assertion that $\mathrm{SoC}$ can be developed in an online learning environment through use of interaction (O’Hara, 2008; Palloff \& Pratt, 1999; Stepich \& Ertmer; 2003). A high level of interaction also appears to be positively correlated with students' SoC (Baab, 2004; Lear, 2007). When examined quantitatively, interaction explains a significant proportion of the variance in community developed by online students (Dawson, 2006).

\section{Theoretical Framework}

Social constructivism (Vygotsky, 1978) views learning as a process in which a learner works to construct new meaning through active involvement. The role of the educator is to establish an environment in which active participation between and among learners and the instructor can occur. The learner must engage in interaction with his or her instructor, peers, and content, and attempt to make sense of what he or she encounters. 
This learner-centered approach holds that, for many students, the one-way flow of information from expert to student that makes up some forms of distance education is less than ideal to foster learning. Most students benefit from the multifaceted mediation of an instructor and interaction with peers as they attempt to make sense of complex content (Wallace, 2003).

In an online education setting, this flow of information is constrained by technology, equipment, and the asynchronous nature of much distance learning. Information flow, therefore, requires attention and planning beyond that needed in a face-to-face educational setting. The instructor must select technologies and tasks that will allow for the communication and exchange of information needed to support construction of knowledge over a distance (Vrasidas, 2000).

Learner-learner, learner-instructor, and learner-content interaction function in an interdependent manner, with each potentially contributing to and benefiting from the others as students and instructor participate in an online learning environment. This interwoven relationship has been described from the perspective of a community of inquiry (CoI) model (Garrison, Anderson, \& Archer, 2000). This framework for effective online learning presents three elements: cognitive presence, social presence, and teaching presence.

Cognitive presence describes the ability of a community of learners to construct meaning through sustained communication. It develops as students collaborate to explore, construct, resolve, and confirm their understanding of content (Garrison, 2007).

Social presence is "the ability of participants in a community of inquiry to project themselves socially and emotionally, as 'real' people (i.e., their full personality), through the medium of communication being used" (Garrison et al., 2000, p. 94). A strong social presence supports cognitive presence. Interactions between learners contribute to the socio-emotional connections that make up social presence. Open communication and group cohesion forged through collaboration are hallmarks of social presence (Garrison, 2007).

Both cognitive and social presence are closely tied to and supported by teaching presence, described as "instructors' ability to project themselves in online courses" (Swan, 2003, p. 24). Teaching presence is comprised of design and organization, facilitation of discourse, and direct instruction (Garrison, 2007). Ke (2010) suggests that teaching presence can serve as both a catalyst to the development of a community of inquiry and a shaper of student cognitive and social performance.

Though cognitive, social, and teaching presence represent psychological constructs that can arise from interaction, Swan (2003) draws parallels between the three presences and interaction types. She suggests that learner-content interaction might be most closely equated with cognitive presence, learner-learner interaction with social presence, and learner-instructor interaction with teaching presence.

While several interaction types can contribute to sense of community, the scope of this pa- 
per is restricted to learner-learner interaction. This focus allows a full consideration of numerous learner-learner interactions while limiting the time commitment for participants and therefore maximizing the survey return rate.

\section{Review of the Literature}

Interactions between a learner and other learners have been viewed for some time as important to building SoC (Wolcott, 1996). A review of the literature resulted in the identification of nine learner-learner interactions that had two or more research studies supporting their contribution to sense of community. This section discusses the empirical support for these interactions.

\section{Opportunities to Learn about Other Students}

The ability to share background information and learn about fellow students is frequently cited in the literature as critical to building SoC in online learning. Establishing commonalities with classmates served to promote online community in Gallagher-Lepak et al.'s (2009) study. In focus groups, these undergraduate students frequently discussed identification of shared interests and experiences as pivotal in developing community.

In a qualitative study, Stallings and Koellner-Clark (2003) examined a number of teaching strategies in a collaborative online classroom using multiple technology formats. They discussed the importance of highly interactive introductions that allow students to get to know one another, and recommended the use of initial face-to-face sessions to facilitate this interaction. Stepich and Ertmer (2003) found that having students post individual introductions helped them to find areas of common interest and background, which facilitated a sense of belonging.

In a mixed methods study, Liu et al. (2007) found a moderately positive relationship between $\mathrm{SoC}$ and social presence in online graduate students. One of the four survey items measuring social presence dealt with familiarity with other students.

\section{Ice-Breaker Activities}

Interactive game-like activities can lead students to develop a greater sense of community. McElrath and McDowell (2008) called for online instructors to involve students in interactive, game-like activities, which lead students to engage with and accept one another, and to be accepted by the online community. Stepich and Ertmer (2003) specifically asked students to make connections online with two or more classmates and engage in conversation about common interests, and reported that this activity helped students build a mutual sense of belonging to the learning community.

\section{Online Discussions}

Online students develop community, construct understanding, and question and clarify content through discussion with other learners. In a constructivist approach, the instructor takes part in these discussions but acts as a facilitator who guides the dialogue, rather than 
controlling it (Nicholson, 2005). Online learning benefits from a balance of whole-class and smaller group discussions (Rovai, 2004). Whole-class discussions are commonly suggested as a means for developing a sense of classroom community (Liu et al., 2007). Adult students in a graduate course indicated that asynchronous class discussions were a significant contributor to their SoC (Rovai, 2001). These students felt they benefited from their classmates' experiences through threaded discussions. The presence of both novice and veteran students in one class can add an element of interdependence among students as they work to construct meaning together (Brown, 2001; Stepich \& Ertmer, 2003). Ke (2010) reports that students may approach enforced online discussions in a superficial manner, and that without appropriate guidance, asynchronous discussions can become grade-driven rather than an exercise in group knowledge construction.

In addition to asynchronous discussion, Rogers, Graham, Rasmussen, Campbell, and Ure (2003) found in their case study involving 19 students in a distance course that both students and instructors valued two-way synchronous discussion for the purpose of asking and answering questions.

\section{Small Group Discussions}

Wolcott (1996) promotes learner-centered activities in online learning, including small group interactions such as discussions, study groups, and cross-group communication to decrease student isolation and enhance communication. Students involved in group discussions are able to work toward academic goals together and to assist and support one another as they become active learners (Aviv, 2000).

\section{Social Communication}

Nicholson (2005) posits that the social component of a typical face-to-face class needs to be purposefully facilitated in online learning in order to support the social growth of students. Rovai (2001) conducted a case study during a five-week graduate level online course. He found that students made use of a social communication forum to pursue connections with one another and to share information and support.

In Liu et al.'s (2007) mixed methods study, interview results indicated that opportunities for social interaction boosted interpersonal relationships and supported positive communications among students. Graduate students in an online instructional design course used an asynchronous social discussion area to express support and encouragement for other students, to discuss similarities, and to share the challenges they faced (Stepich \& Ertmer, 2003). While some students in Conrad's (2002) interpretive study of adult learners expressed appreciation for the opportunity to communicate socially, others said there was a limit to how much time they were willing to spend reading social comments. Participants in Gallagher-Lepak et al.'s (2009) study reported that informal conversations helped them build friendships and camaraderie. They found this communication outside the boundaries of the academic requirements to be important for establishing social bonds and facilitating learning. 


\section{Collaborative Group Projects}

The importance of collaborative group work in building an online sense of community is well established in the literature. Small group activities are positively correlated with SoC (Rovai, 2002a). Rovai (2004) states that small group activities in online learning are consistent with constructivist approaches, and can lead to the development of trust and positive relationships between classmates. Studies have found that students believed collaborative work in their online courses was instrumental in the development of community (Baturay \& Bay, 2010; Conrad, 2005; Gallagher-Lepak et al., 2009). Small group work also has shown a positive effect on learning (Cameron, Morgan, Williams, \& Kostelecky, 2009; Liu et al., 2007).

The idea that an online class community develops primarily among members of small groups rather than across the entire class also has been supported in the literature. Liu et al. (2007) reported that students in an online MBA program formed a community with their group members, but felt little community across the entire class due to limited wholeclass interaction.

\section{Peer Teaching}

In an educational technology online course, graduate students expressed the importance of gaining experience in group leadership (Wegerif, 1998). The authors postulated that the students desired increased control over their online learning experience, and benefited from the opportunity to contribute to its structure.

First-year undergraduates reported satisfaction with peer teaching activities in a blended learning environment that included face-to-face sessions and online activities (Leese, 2009). Students in small groups worked collaboratively to prepare presentations that they would peer-teach during the next session. Students developed increased confidence in working together, presenting to peers, and resolving conflicts.

\section{Exchanging Resources}

Stepich and Ertmer (2003) suggest that when students share resources with one another, they become more responsible for their own learning, their participation is enhanced, and relationships among members of the learning community are strengthened. Participants in Stepich and Ertmer's study found that the instructor was not the only source of information, and they built a shared knowledge base by contributing information sources, techniques, and tools.

In discussing the development of online community in interviews over one year, participating graduate students indicated the importance of providing one another with multiple resources (Haythornthwaite, Kazmer, Robins, \& Shoemaker, 2006). These participants pointed out that the flow of information was reciprocal and helped to build strong ties.

\section{Sharing Personal Experiences}

Graduate level nursing students in an online course reported that they had the opportunity 
to learn from one another's clinical experiences (Ali, Hodson-Carlton, \& Ryan, 2004). They indicated that they valued other students' contributions in this area.

Baab's (2004) mixed methods study found that students receiving the highest classroom community scores reported they shared personal experiences in the context of class discussions and assignments. Participants reported that sharing their experiences enhanced their learning and helped them make connections to the outside world.

\section{Face-to-Face Meetings}

Haythornthwaite et al. (2006) suggest that face-to-face meetings are important for establishing initial bonding between distance students. Participants in Haythornthwaite et al.'s (2006) qualitative study indicated that while some considered live meetings to be an inconvenience, others found the initial face-to-face experience was an important way to unite, establish a shared history, and develop bonds of friendship. Stallings and Koellner-Clark (2003) found that using face-to-face meeting time for highly interactive activities resulted in a stronger classroom community. Students reported that the connections forged in the face-to-face sessions were important for the success of the online components of the class.

Conrad (2005) indicated that graduate students in her qualitative study reported that faceto-face meetings facilitated communication in online components of the course. Students who took advantage of an in-person site visit for a course in Conrad's (2002) study indicated it allowed them to create a special bond with one another. They reported feeling little kinship with the online students who had not attended the site visit.

\section{Research Question}

The research question that guided the study was, What learner-learner interactions in online learning are most predictive of sense of community?

\section{Method}

For this non-experimental, quantitative, descriptive study, all faculty teaching online graduate courses at a South Central U.S. regional comprehensive university during the fall 2011 semester were contacted for permission to survey their students. No limitations were placed with regard to college or department, and faculty members represented a broad range of disciplines. Of the 150 instructors who were contacted, 110 gave permission to survey their students.

Student participants were over the age of 18 years and were taking graduate web courses during the fall 2011 semester. The researchers obtained permission to survey 1,589 unique students representing 2,189 enrollments.

Surveys were sent to 1,589 students through electronic mail. Students received a description of the study, a consent form, a brief demographic questionnaire, the Classroom Community Scale (Rovai, 2002b), and the interaction survey. After two follow-up reminders were sent, students completed 381 usable surveys, giving a response rate of $24 \%$. There 
were 28 partially completed surveys that had insufficient data for inclusion in the analyses. Descriptive statistics were calculated to describe the study sample and population (see Table 1).

Table 1

Descriptive Statistics for the Sample and Population

Mean $S D \quad$ Min. Max. $N$

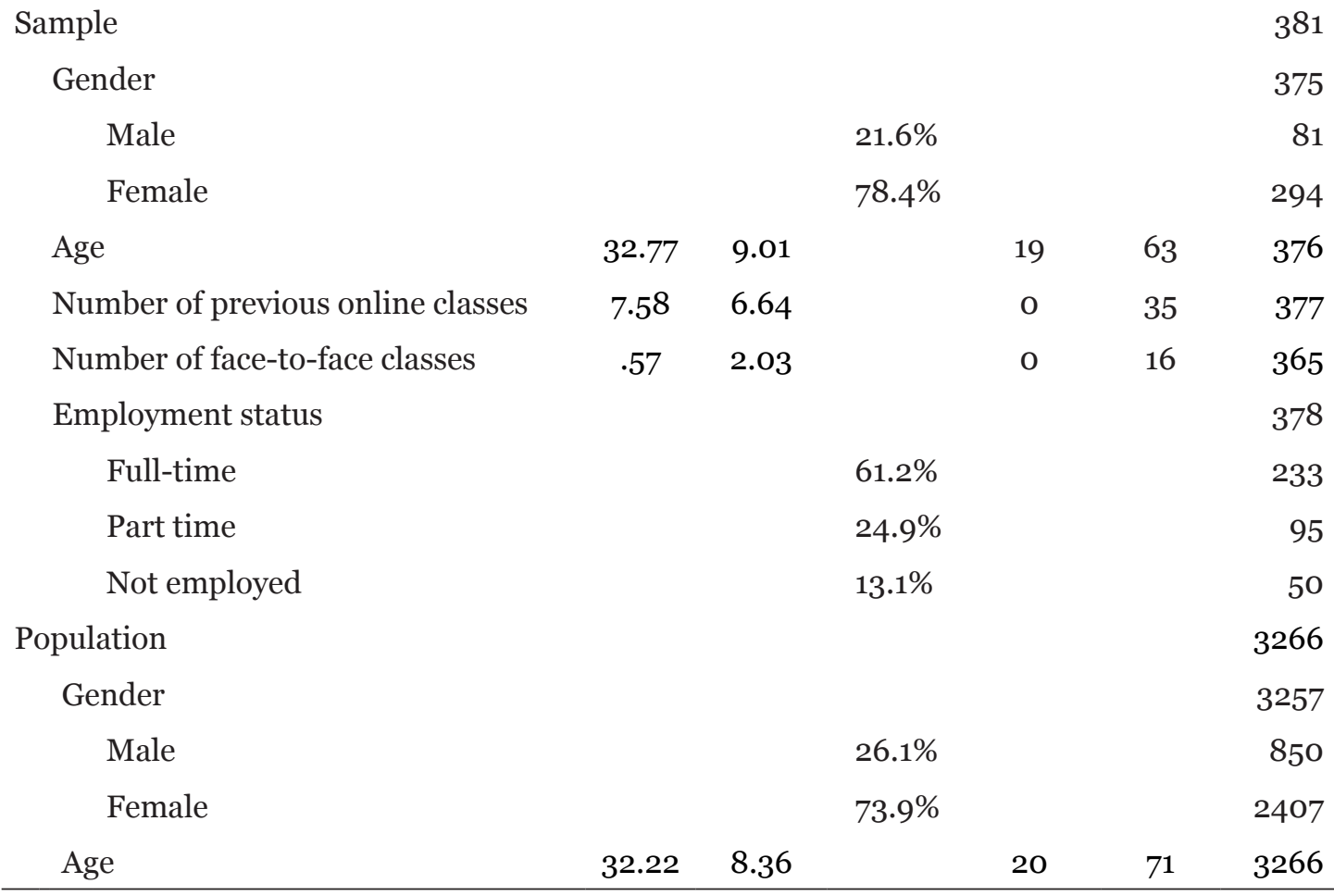

\section{Measures}

The Classroom Community Scale (Rovai, 2002b) was used to measure sense of community. This scale is comprised of 20 Likert items that reflect connectedness and perceived learning in the course. Face validity and construct validity have been established (Rovai, 2002b; Rovai \& Baker, 2005). Internal consistency of the scale items of the CCS have been established in the literature for a number of university undergraduate and graduate populations. Cronbach's $\alpha$ is consistently excellent for this instrument, ranging from .88 to .93 for the overall scale, which indicates evidence of strong reliability (Dawson, 2006; Ritter, Polnick, Fink, \& Oescher, 2010; Rovai \& Baker, 2005; Shea et al., 2006).

Interaction type and frequency were measured using a 32-item Qualtrics survey developed by the author (see Appendix). An extensive review of the literature resulted in the identification of nine learner-learner interactions (Table 2) which had two or more research stud- 
ies supporting their contribution to sense of community. Survey questions were formulated to elicit the students' perceptions of the frequency with which each interaction occurred in their course and the importance of that interaction to their development of community. Face and content validity were determined through a review by a panel of experts and a focus group. A reliability analysis was conducted to determine the internal consistency of the interaction scale.

\section{Variables}

SoC (the dependent variable) was operationalized as the overall score on the Classroom Community Scale (Rovai, 2002b). Frequency of learner-learner interaction was operationalized as participant scores on a 5-point Likert scale, with responses ranging from 1 (Never) to 5 (Very Often). Importance was measured by participant scores on a 5-point Likert scale, with responses ranging from 1 (Not at All) to 5 (Very).

\section{Data Analysis}

Data were entered into SPSS 19.0, with CCS total score as the dependent variable, and interaction items as the independent variables. CCS items that were negatively worded were reverse coded so that a high score indicated a high level of community for all items. The CCS total score was calculated by summing CCS responses for each participant. Multicollinearity diagnostics were conducted, followed by a stepwise linear regression analysis to investigate the amount of variance explained by each type of learner to learner interaction. Demographic variables were entered into the regression model to determine their effect on SoC.

Results were also interpreted using a matrix that identified high and low frequency and high and low perceived importance of learner-learner interactions. This matrix analysis was used to identify the interaction types that could be categorized as low-frequency, high importance items, and high-frequency, high importance items. The items so categorized are expected to be the interaction types that offer the most yield to an instructor in online course design.

Chi-square analyses were conducted to examine the relationship between the frequency and importance of each interaction. Due to the low count in some cells, responses were recoded to collapse data into three categories for each variable. Frequency data from the chisquare analysis were then used to calculate ratios, which placed each type of interaction in a quadrant of an importance-to-frequency scatterplot, with each interaction representing either low importance/low frequency, low importance/high frequency, high importance/ low frequency, or high importance/high frequency (see Figure 1). Low values were defined as less than 1.0, and high values were defined as more than or equal to 1.0.

\section{Results}

A reliability analysis revealed a Cronbach's $\alpha$ of .928 for the CCS scale, indicating the scale has excellent reliability. The Cronbach's $\alpha$ was .880 for the learner-learner frequency items, and .909 for the learner-learner importance items of the interaction scale, indicat- 
ing good reliability.

\section{Research Question Results}

All interaction items were fairly to moderately correlated, with higher CCS total scores (see Table 2). Multicollinearity diagnostics indicated no cause for concern, using a cutoff value of 5 . No VIF values for independent or demographic variables exceeded 1.882.

Table 2

Correlations Between CCS Total Score and L-L Frequency Items

\begin{tabular}{|c|c|c|c|c|c|c|c|c|c|}
\hline & $\begin{array}{c}\text { CCS } \\
\text { total }\end{array}$ & 1 & 2 & 3 & 4 & 5 & 6 & 7 & 8 \\
\hline LLF_1 Introductions & $.595^{*}$ & & & & & & & & \\
\hline LLF_2 Ice-breakers & $.495^{*}$ & $.651^{*}$ & & & & & & & \\
\hline $\begin{array}{l}\text { LLF_3 Online discussions (entire } \\
\text { class) }\end{array}$ & $.408^{*}$ & $.373^{*}$ & $.314^{*}$ & & & & & & \\
\hline $\begin{array}{l}\text { LLF_4 Online discussions (small } \\
\text { group) }\end{array}$ & $.404^{*}$ & $.465^{*}$ & $.382^{*}$ & $.375^{*}$ & & & & & \\
\hline LLF_5 Social communication & $.446^{*}$ & $.531^{*}$ & $.537^{*}$ & $.363^{*}$ & $.410^{*}$ & & & & \\
\hline LLF_6 Collaborative group projects & $.481^{*}$ & $.474^{*}$ & $.524^{*}$ & $.307^{*}$ & $.388^{*}$ & $.500^{*}$ & & & \\
\hline LLF_7 Peer teaching & $.400^{*}$ & $.463^{*}$ & $.504^{*}$ & $.280^{*}$ & $.411^{*}$ & $.435^{*}$ & $.583^{*}$ & & \\
\hline LLF_8 Exchanging resources & $.522 *$ & $.582^{*}$ & $.472^{*}$ & $.392^{*}$ & $.446^{*}$ & $.454^{*}$ & $.481^{*}$ & $.530^{*}$ & \\
\hline $\begin{array}{l}\text { LLF_9 Contributing personal expe- } \\
\text { riences }\end{array}$ & $.520^{*}$ & $.590^{*}$ & $.433^{*}$ & $.410^{*}$ & $.460^{*}$ & $.356^{*}$ & $.412 *$ & $.428^{*}$ & $.582^{*}$ \\
\hline
\end{tabular}

Note. ${ }^{*}$ indicates $p<.05$. LLF $=$ learner-learner frequency

For learner-learner interactions, the regression model was significant $(F=62.861, p<.05)$, with the adjusted $R^{2}$ value indicating that $46 \%$ of the variance is explained by the five predictor variables: introductions, collaborative group projects, contributing personal experiences, entire class online discussions, and exchanging resources (see Table 3). The other items were excluded from the model due to their nonsignificant impact on SoC. 
Table 3

Significance of the Regression Model and Regression Coefficients for Significant Predictors in Learner-Learner Model

$\begin{array}{lcccccc}\text { Model } & F & R^{2} & \text { Adjusted } R^{2} & \beta & t & \text { Sig. } \\ \text { L-L model } & 62.861 & 0.46 & 0.453 & & & \\ \text { LLF_1: Introductions } & & & & 0.307 & 5.847 & 0.000 \\ \text { LLF_6: Collaborative group project } & & & & 0.177 & 3.882 & 0.000 \\ \quad \text { LLF_9: Contribute personal experi- } & & & & 0.138 & 2.655 & 0.008 \\ \text { ences } & & & 0.133 & 3.080 & 0.002 \\ \quad \text { LLF_3: Entire class online discussions } & & & 0.126 & 2.396 & 0.017 \\ \text { LLF_8: Exchange resources } & & & & & \end{array}$

Note. $\mathrm{LLF}=$ learner-learner frequency

The authors conducted an analysis of the demographic variables, number of previous online courses, number of face-to-face class meetings, gender, age, and employment status-with $\mathrm{SoC}$ as the dependent variable. The variable number of previous online courses, as a measure of experience with online learning, had a significant effect on $\operatorname{SoC}(p<.05)$. Employment status, number of face-to-face class meetings, gender, and age had a nonsignificant effect on SoC. It should be noted that the sample was homogeneous with regard to the number of reported face-to-face meetings. Fully $80 \%$ of participants (295 out of 365) reported no face-to-face meetings in their class. Such a homogeneous sample may be insufficient for this demographic variable to be a valid representation of the effect of face-to-face meetings.

Chi-square results showed that for each type of learner-learner interaction, frequency was significantly related to importance. For all types of interaction, the relationship was positive in direction. As shown in Figure 1, Item 8 (exchanging resources) was a high importance/ low frequency item for learner-learner interaction. This item occurred infrequently among students, but was considered highly important for building SoC. Items 4 (small group discussions), 9 (contributing personal experiences), and 3 (entire class discussions) were high importance/high frequency items. 


\section{Importance:Frequency Ratios for Learner-Learner Items}

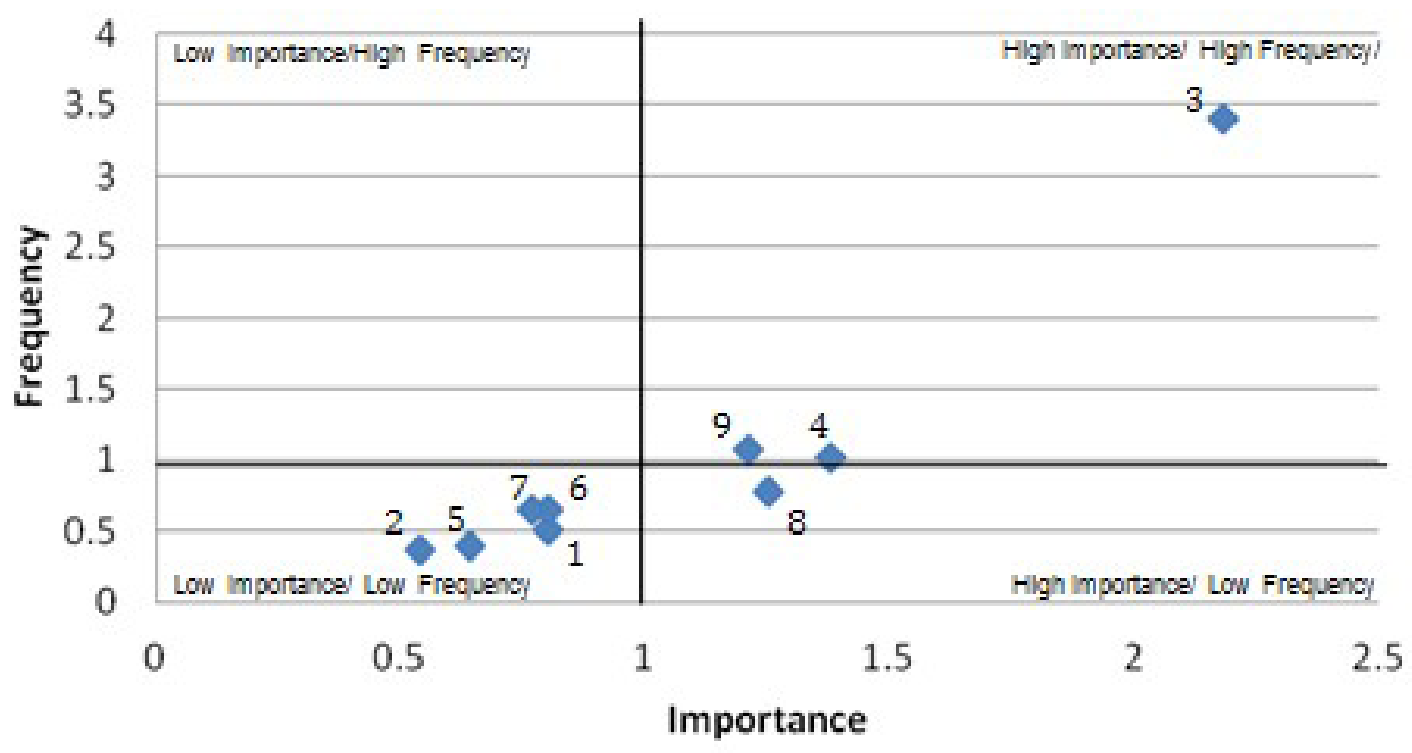

Figure 1. Importance-to-frequency ratios for learner-learner interaction items. In this matrix analysis, four quadrants of low and high frequency and low and high importance are delineated by horizontal and vertical black lines along the 1.0 value markers. Points are ratios of frequency to importance for each interaction item: (1) introductions, (2) icebreakers, (3) entire class discussions, (4) small group discussions, (5) social communication, (6) collaborative group projects, (7) peer teaching, (8) exchanging resources, and (9) contributing personal experiences.

\section{Discussion}

The results of this study revealed that interactions are correlated with sense of community and identified a number of interactions that contribute to SoC.

\section{Learner-Learner Interactions}

Interactions between learners which emerged as contributing the most to sense of community, in decreasing order of contribution, were (a) introductions, (b) collaborative group projects, (c) contributing personal experiences, (d) entire class online discussions, and (e) exchanging resources.

These results support the findings of Gallagher-Lepak et al. (2009) and Stepich and Ertmer (2003) that indicate that introductions at the beginning of an online class allow students to establish commonalities upon which they can build throughout the semester. Introductions may allow students to get off to an early start with online community-building, which allows them more time to develop a rich sense of community.

The emergence of collaborative group projects as a contributor to SoC supports the exten- 
sive literature that promotes getting students to work as a team on shared projects to bring them together (Baturay \& Bay, 2010; Conrad, 2005; Gallagher-Lepak et al., 2009; Rovai, 2002a; Rovai, 2004).

Contributing personal experiences explained almost $14 \%$ of the variance in SoC. While this type of interaction has not received much attention in the online learning literature (Ali et al., 2004; Wolcott, 1996; and Baab, 2004), it is apparent that giving students an opportunity to express how class content relates to their life or professional experience is important in terms of building connectedness and shared learning.

Academic discussion involving the entire class is an intuitive contributor to community. It is in this venue that students question content, seek clarification, build their understanding, and begin to form an impression of their peers in the class (Liu et al., 2007; Rovai, 2001).

Finally, exchanging resources emerged as a contributor to SoC, supporting Stepich and Ertmer (2003) and Haythornthwaite et al. (2006), who promoted the idea that when students share information, documents, and techniques, they become more responsible for their own learning and find they have resources beyond the instructor upon whom they can depend. They learn they have peers with whom they can enter into a mutually supportive relationship as they struggle to learn and manage their responsibilities.

\section{Contribution of Demographic Characteristics to Interaction}

Only the number of previous online courses emerged as a contributor to SoC. This result supports the work of Brown (2001), Gallagher-Lepak et al. (2009), Lear (2007), and Rovai (2001). Veteran distance learners, no longer burdened with the double task of learning content and technology, tend to interact and work toward building community with their peers more than novice online learners. They have learned through experience that community can be established in an online course, and they begin early in the semester to make the contacts that will support their connectedness and learning. Age, gender, and employment status did not appear to contribute to $\mathrm{SoC}$ in this sample, as would be expected based on findings in studies by Exter et al. (2009) and Gallagher-Lepak et al. (2009).

\section{High-Yield Interactions}

The interaction type that offers the highest payoff for the instructor in terms of balance between effort and benefit is exchanging resources; it offered the highest yield. While four of the nine learner-learner interaction types were viewed by students as highly important in building SoC (small group discussions, entire class discussions, the opportunity to contribute personal experiences, and exchanging resources with peers), only exchanging resources was viewed as highly important, even though it did not occur often. This indicates that this interaction appears to offer the greatest yield to the busy instructor who seeks to facilitate community.

\section{Limitations}

The limitations of this study were related to the nature of data collection and generalizability. The surveys measured the perception of human interaction events, and there is always room for interpretation of social constructs of this kind. Due to the timing of the data col- 
lection, which took place three weeks before the end of the semester, some interaction types might have been underrepresented.

The sample was drawn from one university, so results may not apply to students at other universities. The low response rate to the survey further limits generalizability.

\section{Future Research}

Future studies on this topic could collect data at the end of the semester to provide better representation of interaction types that tend to occur late in the semester. An investigation of the interactions valued by students in cohort models would be of interest. Sampling across multiple universities would provide a more diverse population. Further research might also use qualitative methods to shed light on the reasons why some interaction types emerge as low or high importance.

\section{Implications}

An instructor who wants to facilitate $\mathrm{SoC}$ can build learner-learner interaction into online courses in a number of ways. He or she should provide an opportunity for students to get to know one another early in the semester. This enables students to establish commonalities and connections that increase their comfort with contacting one another. These contacts encourage further interaction throughout the semester, leading to an increased SoC.

Use of collaborative group projects can encourage students to work as a team. The instructor, however, must provide sufficient direction and support to improve the chances that this teamwork will be positive and contribute to sense of community.

It is important to allow students the opportunity to contribute brief stories about their own experiences during either asynchronous threaded discussions or synchronous discussions. Not all students will want or need to contribute, but the chance to connect personally to academic content will benefit those who do participate.

Requiring class discussions on academic topics encourages students to negotiate meaning and to learn from one another. These discussions can be synchronous or asynchronous.

The instructor should talk with students early in the semester about the benefits of sharing learning resources with one another. Experienced online learners can support novice learners, and students with expertise or skills in a particular professional area can contribute to the success of peers in the class by sharing resources such as documents, research articles, formatting tips, or links to topics of academic interest. Social media can be suggested as a means of sharing resources.

The message of this study is that in this age of dazzling technology, there is still no substitute for interaction, and there must be opportunities for students to interact in multiple ways with their peers in an online environment. An instructor who desires to retain students through facilitating SoC has many tools for building interaction into an online 
course. Through purposeful use of activities that incorporate interaction among students, the instructor can create a welcoming and accepting online course in which students have a sense of belonging and trust. 


\section{References}

Ali, N. S., Hodson-Carlton, K., \& Ryan, M. (2004). Students' perceptions of online learning: Implications for teaching. Nurse Educator, 29, 111-115.

Anderson, T., \& Elloumi, F. (2004). Theory and practice of online learning. Edmonton, AB: Athabasca University Press. Retrieved from http://cde.athabascau.ca/online_ book/

Aviv, R. (2000). Educational performance of ALN via content analysis. Journal of Asynchronous Learning Networks, 4(2), 53-72.

Baab, L. (2004). Effect of selected factors on students' sense of classroom community in distance learning courses (Doctoral dissertation). Available from Proquest Dissertations and Theses database. (UMI No. 3150346)

Baturay, M. H., \& Bay, O. F. (2010). The effects of problem-based learning on the classroom community perceptions and achievement of web-based education students. Computers \& Education, 55(1), 43-52.

Brown, R. E. (2001). The process of community-building in distance learning classes. Journal of Asynchronous Learning Networks, 5(2), 18-35.

Cameron, B. A., Morgan, K., Williams, K. C., \& Kostelecky, K. L. (2009). Group projects: Student perceptions of the relationship between social tasks and a sense of community in online group work. American Journal of Distance Education, 23(1), 20-33.

Conrad, D. (2002). Deep in the hearts of learners: Insights into the nature of online community. Journal of Distance Education, 17(1), 1-19.

Conrad, D. (2005). Building and maintaining community in cohort-based online learning. Journal of Distance Education, 20(1), 1-20.

Dawson, S. (2006). A study of the relationship between student communication interaction and sense of community. Internet and Higher Education, 9, 153-162.

Drouin, M. A. (2008). The relationship between students' perceived sense of community and satisfaction, achievement, and retention in an online course. Quarterly Review of Distance Education, 9, 267-284.

Exter, M. E., Korkmaz, N., Harlin, N. M., \& Bichelmeyer, B. A. (2009). Sense of community within a fully online program: Perspectives of graduate students. Quarterly Review of Distance Education, 10, 177-194.

Gallagher-Lepak, S., Reilly, J., \& Killion, C. (2009). Nursing student perceptions of com- 
munity in online learning. Contemporary Nurse: A Journal for the Australian Nursing Profession, 32, 133-146.

Garrison, D. R. (2007). Online community of inquiry review: Social, cognitive, and teaching presence issues. Journal of Asynchronous Learning Networks, 11(1), 61-72.

Garrison, D. R., Anderson, T., \& Archer, W. (2000). Critical inquiry in a text-based environment. Computer Conferencing in Higher Education, 2, 87-105.

Haythornthwaite, C., Kazmer, M. M., Robins, J., \& Shoemaker, S. (2006). Community development among distance learners: Temporal and technological dimensions. Journal of Computer-Mediated Communication, 6(1). doi:10.1111/j.1083-6101.200o. tboo114.x

Hillman, D. C. A., Willis, D. J., \& Gunawardena, C. N. (1994). Learner-interface interaction in distance education: An extension of contemporary models and strategies for practitioners. American Journal of Distance Education, 8(2), 30-42.

Ke, F. (2010). Examining online teaching, cognitive, and social presence for adult students. Computers \& Education, 55, 808-820.

Lear, J. (2007). Interactive class design and sense of community in online distance education classes: A mixed methods research study (Doctoral dissertation). Available from Proquest Dissertations and Theses database. (UMI No. 3321124)

Leese, M. (2009). Out of class-out of mind? The use of a virtual learning environment to encourage student engagement in out-of-class activities. British Journal of Educational Technology, 40, 70-77. doi:10.1111/j.1467-8535.2008.00822.x

Liu, X., Magjuka, R. J., Bonk, C. J., \& Lee, S. (2007). Does sense of community matter? Quarterly Review of Distance Education, 8, 9-24.

McElrath, E., \& McDowell, K. (2008). Pedagogical strategies for building community in graduate level distance education courses. MERLOT Journal of Online Learning and Teaching, 4, 117-127.

McInnerney, J. M., \& Roberts, T. S. (2004). Online learning: Social interaction and the creation of a sense of community. Educational Technology \& Society, 7(3), 73-81.

McMillan, D. W., \& Chavis, D. M. (1986). Sense of community: A definition and theory. Journal of Community Psychology, Psychological Sense of Community, I: Theory and Concepts, 14(1), 6-23.

Moller, L. (1998). Designing communities of learners for asynchronous distance education. Educational Technology Research and Development, 46(4), 115-122.

Moore, M. (1989). Editorial: Three types of interaction. American Journal of Distance Ed- 
ucation, 3(2), 1-7.

Nicholson, S. (2005). A framework for technology selection in a web-based distance education environment: Supporting community-building through richer interaction opportunities. Journal of Education for Library and Information Science, 46, 217.

O'Hara, L. J. (2008). An investigation of the formation of learning community in webbased distance education (Doctoral dissertation). Retrieved from http://challenger.library.pitt.edu/ETD/available/etd-04302008-092522/

Ouzts, K. (2006). Sense of community in online courses. Quarterly Review of Distance Education, 7, 285-296.

Palloff, R., \& Pratt, K. (1999). Building learning communities in cyberspace. San Francisco, CA: Jossey-Bass.

Parry, M. (2010, January 26). Wired campus: Colleges see 17 percent increase in online enrollment [Web log post]. Retrieved from http://chronicle.com/blogs/wiredcampus/colleges-see-17-percent-increase-in-online-enrollment/20820

Ritter, C., Polnick, B., Fink, R., \& Oescher, J. (2010). Classroom learning communities in educational leadership: A comparison study of three delivery options. Internet and Higher Education, 13, 96-100.

Rogers, P. C., Graham, C. R., Rasmussen, R., Campbell, J. O., \& Ure, D. M. (2003). Case 2: Blending face-to-face and distance learners in a synchronous class: Instructor and learner experiences. Quarterly Review of Distance Education, 4, 245-51.

Rovai, A. (2001). Building classroom community at a distance: A case study. Educational Technology Research and Development, 49(4), 33-48.

Rovai, A. P. (2002a). Building sense of community at a distance. International Review of Research in Open and Distance Learning, 3(1). Retrieved from http://www.irrodl. org/index.php/irrodl/article/view/79

Rovai, A. P. (2002b). Development of an instrument to measure classroom community. Internet and Higher Education, 5, 197-211. (ERIC Document Reproduction Service No. EJ663068)

Rovai, A. P. (2004). A constructivist approach to online college learning. Internet and Higher Education, 7, 79-93.

Rovai, A. P., \& Baker, J. D. (2005). Gender differences in online learning. Quarterly Review of Distance Education, 6, 31-44.

Shea, P. (2006). A study of students' sense of learning community in online environments. Journal of Asynchronous Learning Networks, 10(1), 35-44. 
Shea, P., Li, C. S., \& Pickett, A. (2006). A study of teaching presence and student sense of learning community in fully online and web-enhanced college courses. Internet and Higher Education, 9, 175-190.

Stallings, L. L., \& Koellner-Clark, K. (2003). Re-creating graduate teacher education classrooms: Multiple technology formats and collaborating instructors. Journal of Technology and Teacher Education, 11, 501-514.

Stepich, D. A., \& Ertmer, P. A. (2003). Building community as a critical element of online course design. Educational Technology, 43(5), 33-43.

Swan, K. (2003). Learning effectiveness: What the research tells us. In J. Bourne \& J. C. Moore (Eds.), Elements of quality online education, practice and direction (pp. 13-45). Needham, MA: Sloan Center for Online Education.

Vrasidas, C. (2000). Constructivism versus objectivism: Implications for interaction, course design, and evaluation in distance education. International Journal of Educational Telecommunications, 6, 339-362.

Vrasidas, C., \& McIsaac, M. S. (1999). Factors influencing interaction in an online course. American Journal of Distance Education, 13, 22-36.

Vygotsky, L. S. (1978). Mind in society. Cambridge, MA: MIT Press.

Wagner, E. D. (1994). In support of a functional definition of interaction. American Journal of Distance Education, 8, 6-29.

Wallace, R. M. (2003). Online learning in higher education: A review of research on interactions among teachers and students. Education, Communication and Information, 3, 241.

Wegerif, R. (1998, March). The social dimension of asynchronous learning networks. The Journal of Asynchronous Learning Networks, 2(1).Sloan Consortium. Retrieved from http://sloanconsortium.org/jaln/v2n1/social-dimension-asynchronouslearning-networks

Wolcott, L. L. (1996). Distant, but not distanced: A learner-centered approach to distance education. TechTrends, 41(5), 23-27.

Yang, H. H., \& Liu, Y. (2008). Building a sense of community for text-based computermediated communication courses. Journal of Educational Technology Systems, $36,393-413$. 


\section{Appendix: Interaction Scale}

Directions: The following statements relate to interactions between you and other students in your class. Please indicate how often these interactions happened in this class.

FREQUENCY: In this class, how often did you:

\begin{tabular}{|l|l|l|l|l|l|}
\hline $\begin{array}{l}\text { have the opportunity to get to know } \\
\text { classmates by sharing information } \\
\text { about yourselves? }\end{array}$ & Never & Rarely & Occasionally & Often & Very often \\
\hline $\begin{array}{l}\text { participate in an activity (such as a } \\
\text { game or ice breaker) to get to know } \\
\text { classmates? }\end{array}$ & Never & Rarely & Occasionally & Often & Very often \\
\hline $\begin{array}{l}\text { take part in online discussions with the } \\
\text { entire class? }\end{array}$ & Never & Rarely & Occasionally & Often & Very often \\
\hline $\begin{array}{l}\text { take part in small group discussions } \\
\text { online? }\end{array}$ & Never & Rarely & Occasionally & Often & Very often \\
\hline $\begin{array}{l}\text { communicate with other students } \\
\text { about non-academic topics (such as an } \\
\text { open discussion board, Water Cooler } \\
\text { forum, etc.)? }\end{array}$ & Never & Rarely & Occasionally & Often & Very often \\
\hline $\begin{array}{l}\text { work with a group of classmates on a } \\
\text { collaborative project? }\end{array}$ & Never & Rarely & Occasionally & Often & Very often \\
\hline $\begin{array}{l}\text { take part in peer teaching (such as giv- } \\
\text { ing presentations or leading discus- } \\
\text { sions)? }\end{array}$ & Never & Rarely & Occasionally & Often & Very often \\
\hline $\begin{array}{l}\text { exchange resources (such as links or } \\
\text { documents) and information with } \\
\text { classmates? }\end{array}$ & Never & Rarely & Occasionally & Often & Very often \\
\hline $\begin{array}{l}\text { contribute personal experiences as } \\
\text { they relate to course content? }\end{array}$ & Never & Rarely & Occasionally & Often & Very often \\
\hline
\end{tabular}

IMPORTANCE: How important were each of these interactions in contributing to your sense of community in this course?

\begin{tabular}{|l|l|l|l|l|l|}
\hline $\begin{array}{l}\text { have the opportunity to get to know } \\
\text { classmates by sharing information } \\
\text { about yourselves? }\end{array}$ & Not at all & Slightly & Fairly & Quite & Very \\
\hline
\end{tabular}




\begin{tabular}{|l|l|l|l|l|l|}
\hline $\begin{array}{l}\text { participate in an activity (such as a } \\
\text { game or ice breaker) to get to know } \\
\text { classmates? }\end{array}$ & Not at all & Slightly & Fairly & Quite & Very \\
\hline $\begin{array}{l}\text { take part in online discussions } \\
\text { with the entire class? }\end{array}$ & Not at all & Slightly & Fairly & Quite & Very \\
\hline $\begin{array}{l}\text { take part in small group discus- } \\
\text { sions online? }\end{array}$ & Not at all & Slightly & Fairly & Quite & Very \\
\hline $\begin{array}{l}\text { communicate with other students } \\
\text { about non-academic topics (such } \\
\text { as an open discussion board, Wa- } \\
\text { ter Cooler forum, etc.)? }\end{array}$ & Not atl & Slightly & Fairly & Quite & Very \\
\hline $\begin{array}{l}\text { work with a group of classmates on } \\
\text { a collaborative project? }\end{array}$ & Not at all & Slightly & Fairly & Quite & Very \\
\hline $\begin{array}{l}\text { take part in peer teaching (such } \\
\text { as giving presentations or leading } \\
\text { discussions)? }\end{array}$ & Not at all & Slightly & Fairly & Quite & Very \\
\hline $\begin{array}{l}\text { exchange resources (such as links } \\
\text { or documents) and information } \\
\text { with classmates? }\end{array}$ & Not at all & Slightly & Fairly & Quite & Very \\
\hline $\begin{array}{l}\text { contribute personal experiences as } \\
\text { they relate to course content? }\end{array}$ & Not at all & Slightly & Fairly & Quite & Very \\
\hline
\end{tabular}

\section{Demographic Questions}

Approximately how many online courses have you taken prior to this course?

Pull-down menu (0-50)

Did your entire class meet in person in a physical classroom at least once during the semester?

Yes No

What is your employment status?

Employed full time Employed part time Not currently employed

What is your gender?

Male Female

What is your age?

Pull-down menu (18-99) 


\section{Athabasca University $\mathbf{1}$}

(c) (†) 